\title{
Determinants of Bank Profitability in Ghana: New Evidence
}

\author{
Daniel Anarfi \\ Faculty of Economics, Mendel University in Brno, Czech Republic \\ E-mail: anarfidaniel@ymail.com
}

Emmanuel Joel Aikins Abakah

School of Business, University of Adelaide, Australia

E-mail: ejabakah@gmail.com

\author{
Eunice Boateng \\ All African Students Union (ASU) - Ghana \\ E-mail: eunniceboateng@gmail.com
}

Received: Nov.7, 2016 Accepted: Nov. 29, $2016 \quad$ Published: December 1, 2016

doi:10.5296/ajfa.v8i2.10274 URL: http://dx.doi.org/10.5296/ajfa.v8i2.10274

\begin{abstract}
This study examines the determinants of profitability in the Ghanaian Banking Industry for an eight (8) year period of 2007 to 2014. Using a sample from 9 local banks and 12 foreign banks in Ghana, the study combines bank-specific determinants and macroeconomic variables to access bank profitability with Return on Assets (ROA) as the dependent variable. The Hausman specification test was performed on a panel regression to determine the appropriate model for this study. The estimation results shows that, bank SIZE and DEPOSITS are not significant and does not impact profitability. However, LOANS, CAPITAL and OVERHEADS were found to be significant and impacts on profitability. The study concludes that banks in Ghana should be technological in their operations to reduce staff cost since the OVERHEAD was highly significant and impacts negatively on ROA.
\end{abstract}

Keywords: Bank Profitability, Determinants, Return on Assets 


\section{Introduction}

The objective of this study is to investigate the determinants banks profitability for the period of 2007-2014. Today banks have a key role in all countries and their policies and strategies affect economic development unemployment, prices, national income, etc. (Goodhart, 2016). Several banking empirical literature provides evidence to back the claim that banking operations is predominantly fundamental to the economic wellbeing of most countries in the world (Ayadi et al., 2015; Naceur \& Ghazouani, 2007; Shahbaz \& Lean, 2012; Van Nieuwerburgh et al., 2006). Haghighat and Nasiri (2004) also confirms this claim that any activity which requires investments and financial resources requires the involvement of banks and financial institutions. One important role which both Bank Financial Institutions and Non-Bank Financial Institutions plays in an economy is that, when there is a support of efficient money and capital markets in the financial system, it enhances the overall growth of the economy (Lee \& Heshmati, 2009).

Traditionally, the primary role of financial institutions is to provide financial intermediation by collecting and mobilizing resources to finance business and development projects that are essential for economic development (Nwaeze, Michael \& Nwabekee, 2014). An efficient financial system is an important factor for the efficient financial intermediation which leads to sustainable private sector investment and the promotion of entrepreneurship (Yaron et., 1998). As such, an understanding of the determinants of the profitability of financial institutions such as the banks is essential and crucial to the stability of the economy. Lartey et al., (2013) defines Bank profitability as the ability of a bank to generate revenue in excess of cost, in relation to the bank's capital base. In this study, an attempt is made to investigate some key determinants of profitability and the extent to which they impact on profitability of banks. The analysis will adopt a fixed and random effect model with data pooled from annual financial statements of 21 banks over the period 2007-2014.The rest of the paper is organized as follows; the next section describes the data and the econometric methodology, followed by presentation of analyses and the empirical results. The last section concludes and offers some policy recommendations.

\section{Data and Methodology}

This study used a strongly balanced panel of 21 banks operating in the Ghanaian Banking industry. The 21 banks consist of 9 local banks and 12 foreign banks. We use the bank's annual and macroeconomics data in Ghana for an 8 year period of 2007 - 2014 yielding a total of 127 year bank observations. The bank's annual data was obtained from their annual income statements and balance sheets as well as ratios from the Ghana Banking survey which is published annually by PricewaterhouseCoopers (PWC) Ghana while the macroeconomics data was obtained from the World Bank database and the Bank of Ghana database. For estimation purposes, we propose the following general linear model:

$$
R O A_{i t}=\alpha+\sum_{a l l}^{n} \beta_{i} X_{i t}+\sigma_{i t}+\varepsilon
$$


Where $R O A_{i t}$ is the return on assets of bank iat timet; $\alpha$ is the regression constant; $X_{i t}$ denote the denote vectors of bank-specific and the macroeconomic determinants; $\sigma_{i t}$ is the unobserved bank-specific effect, and $\varepsilon$ is the error term.

\section{Dependent variable}

We carried out an empirical analyse to test the relationship that exist between dependent and the independent variables. The dependent variable used in this study is the return on asset (ROA) and is the proxy for measuring the bank's profitability. According to Obamuyi (2013), the return on assets (ROA) is a financial ratio used to measure the relationship of earnings to total assets. The ROA is preferred to the use of return on equity (ROE) or net interest margin because it assesses how efficiently the banks manages its revenues and expenses from operations, and also reflects the ability of the management to generate profits by using the available financial and real assets (Obamuyi, 2013; Jahan, 2012). Also the ROA as a measurement for bank profitability shows bank management's efficiency in managing its capitals to acquire assets and make earnings from it (Jamal \& Karim, 2012). Other authors who have used the ROA as a measure of profitability in several disciplines include Babalola (2012) Flamini et al., (2009); Oladele et al., (2012); Arias (2011).

\section{Explanatory Variables}

Two categories of explanatory variables (Bank-Specific variables and Macro-economic variables) were used to determine the bank profitability in the Ghanaian banking industry.

\section{Bank-Specific Determinants}

Basically the bank specific determinants are the internal factors that are used to measure the profitability of banks. The following bank-specific determinants were considered for the purpose of this paper:

- Asset size: Most literature have considered total assets of the banks as a proxy for bank size and is represented by natural logarithm of total asset $(\log$ A) (Anbar \& Anper, 2011).

- Bank Loan: The ratio of bank's loans to total assets was also used as part of the explanatory variables. The traditional banking practice among Ghanaian Banks is accepting deposits and transforming them into loans. Interest is charge on these loans which serves as their principal source of income.

- Bank Deposits: The ratio of total deposits to total assets which is another liquidity indicator but is considered as a liability. Thisis the main source of banks funding and isalso the lowest cost of funds. The more deposits are transformed into loans, the higher the interest margin and profit. Therefore deposits have positive an impact on profitability of the banks.

- Capital: This is the ratio of the bank's equity capital to total assets. According to Berger (1995), there is a positive relationship between the level of capital and the profitability of the banks and when the level of capital is high, the bank can have excess funds to give out as loans after meeting the requirement of the regulator. 
- Overhead: We again use the ratio of overhead to total assets to capture the variations of cost in the Ghanaian banking industry. This is the various components of wages and salaries provided to employees and is expected to have a negative effect on profitability.

\section{Macro-Economic Determinants}

Three macro-economic variables were used in this paper. The first is the GDP per capital growth. There is an extant literature to show that GDP has a positive impact on performance of banks (Naceur, 2003). Also, GDP reflects the upswings and downswing in the business industry. Moreover, exchange rate - EXR and interest rate -ITR were the other two macro-economic variables used in this study.

The panel nature of the data sample allows the application of fixed-effects (FE), random effect (RE) methods on the variables (Anarfi \& Boateng, 2016). The Hausman specification test was conducted to compare the two categories of specifications and to determine the appropriate model for the study.

Table 1. Description of the variables Used in the Regression Models

\begin{tabular}{|c|c|c|c|}
\hline Variable & Description & $\begin{array}{l}\text { Hypothesized } \\
\text { Relationship } \\
\text { Profitability }\end{array}$ & with \\
\hline \multicolumn{4}{|l|}{ Dependent } \\
\hline ROA & $\begin{array}{l}\text { The return on average total assets of bank } i \text { at } \\
\text { time } t\end{array}$ & & NA \\
\hline \multicolumn{4}{|l|}{ Independent } \\
\hline & Bank-Specific Determinants & & \\
\hline SIZE & $\begin{array}{l}\text { The natural logarithm of the accounting value of } \\
\text { bank } i \text { at time } t\end{array}$ & & $+/-$ \\
\hline LOAN & $\begin{array}{l}\text { A measure of liquidity which is calculated as } \\
\text { total loans/total assets }\end{array}$ & & + \\
\hline DEPOSIT & Calculated as total deposits/total assets & & $+/-$ \\
\hline CAPITAL & Calculated as total capital/total assets & & $+/-$ \\
\hline \multirow[t]{2}{*}{ OVERHEAD } & $\begin{array}{l}\text { Calculated as total overheads/total assets. The } \\
\text { various components of wages and salaries } \\
\text { provided to employees }\end{array}$ & & - \\
\hline & Macro-Economic Determinants & & \\
\hline GDP & Gross Domestic Product & & $+/-$ \\
\hline EXR & $\begin{array}{l}\text { Official exchange rate (GHS per US\$, period } \\
\text { average) }\end{array}$ & & $+/-$ \\
\hline ITR & The rate charged by banks on loans to banks & & $+/-$ \\
\hline
\end{tabular}

Source: author's estimations 


\section{Empirical Results}

The results of the study are presented in this section. The results presented include the descriptive statistics, correlation matrix and econometric results which is relevant for the study.

\subsection{Descriptive statistics}

Table 2 below indicates the mean values, standard deviation, the minimum and maximum values for each variable in the study.

Table 2. Descriptive Statistics

\begin{tabular}{lllll}
\hline Variable & Mean & Std. & Min & Max \\
& & Dev. & & \\
\hline ROA & 2.395333 & 3.197508 & -20.6 & 8.5 \\
SIZE & 20.055 & 1.725792 & 11 & 22.46 \\
LOAN & 58.01205 & 13.20192 & 15 & 89 \\
DEP & 70.92169 & 20.04782 & 0 & 139 \\
CAP & 16.11102 & 13.67277 & 0 & 96 \\
OVERHEAD & 8.171429 & 3.669714 & 1 & 25 \\
GDP & 7.61125 & 3.135672 & 3.99 & 14.05 \\
EXR & 1.5625 & 0.447365 & 0.94 & 2.4 \\
ITR & 15.8125 & 2.641044 & 12.5 & 21 \\
\hline
\end{tabular}

Source: authors' estimations

Table 2 above shows the basic descriptive statistics of the variables used for this study. For each variable, the table shows the mean, standard deviation, minimum and maximum value. On average, banks considered in our sample have a return on assets ROA of $2.4 \%$ for the 8 year period from 2007 to 2014 . The standard deviation of ROA is $3.19 \%$ with a minimum and maximum values are $-20.6 \%$ and $8.5 \%$, respectively. When the mean of bank size (SIZE) is $20.05 \%$, minimum value is $11 \%$ and maximum value is $22.46 \%$ with a standard deviation of $1.72 \%$. Again the table shows that, on average the banks give $58.01 \%$ loans and advances/assets to its customers. The minimum and maximum value of loans which the banks can give out is $11 \%$ and $89 \%$ respectively which can deviate by $13.20 \%$. Averages of deposits/Assets (DEP) and capital/assets (CAP) are approximately $71 \%$ and 16\%, respectively. The bank cost which is represented by the OVERHEADS to total assets also recorded an average of $8.17 \%$, where the highest it can reach is $25 \%$. On the other hand, the table also shows the mean of macroeconomic variables over the period considered for this study. On the average the growth rate of GDP is approximately $7 \%$ (minimum 3.99\% and maximum of 
$14.05 \%)$. When the mean of real exchange rate is $1.5 \%$, real interest rate has a $15.8 \%$ mean value for 2007-2014 periods.

\subsection{Correlation Analysis}

The table below explains the correlation of the profitability variable (ROA)with that of the factors which influences profitability in the Ghanaian Banking industry.

Table 3. Correlation Matrix

\begin{tabular}{lrrrrrrrrr}
\hline & \multicolumn{1}{l}{ ROA } & \multicolumn{1}{c}{ SIZE } & LOAN & DEP & CAP & OVER & GDP & EXR & ITR \\
\hline ROA & 1.0000 & & & & & & & & \\
SIZE & $0.4430^{*}$ & 1.0000 & & & & & & & \\
& 0.0000 & & & & & & & & \\
LOAN & -0.0313 & -0.1111 & 1.0000 & & & & & & \\
& 0.6905 & 0.1581 & & & & & & & \\
DEP & -0.0338 & 0.1347 & 0.0003 & 1.0000 & & & & & \\
& 0.6677 & 0.0864 & 0.9967 & & & & & & \\
CAP & 0.0961 & $-0.4220^{*}$ & $-0.1892^{*}$ & $-0.3918^{*}$ & 1.0000 & & & & \\
& 0.221 & 0.0000 & 0.0146 & 0.0000 & & & & & \\
OVER. & $-0.5723^{*}$ & $-0.2099^{*}$ & 0.0758 & 0.0089 & -0.0929 & 1.0000 & & & \\
& 0.0000 & 0.0135 & 0.3732 & 0.9165 & 0.2749 & & & & \\
GDP & -0.1275 & -0.0680 & -0.1499 & 0.0288 & -0.0591 & 0.0508 & 1.0000 & & \\
& 0.1028 & 0.3869 & 0.0538 & 0.7125 & 0.4491 & 0.5512 & & & \\
EXR & $-0.2464^{*}$ & $-0.4557^{*}$ & $0.1857^{*}$ & -0.0873 & -0.0244 & 0.0700 & -0.1299 & 1.0000 & \\
& 0.0014 & 0.0000 & 0.0166 & 0.2635 & 0.7549 & 0.4112 & 0.0933 & & \\
ITR & 0.1184 & $0.1820^{*}$ & 0.0608 & 0.0367 & -0.0546 & 0.028 & $-0.2816^{*}$ & $-0.3828^{*}$ & 1.0000 \\
& 0.1298 & 0.0197 & 0.4365 & 0.6387 & 0.4845 & 0.7423 & 0.0002 & 0.0000 & \\
\hline
\end{tabular}

Source: authors' estimations

The above table shows the correlation analysis between the dependant variable and the independent variables. With our micro level variables, firm SZE and OVERHEADS are significantly impacting on ROA. The correlation between SIZE and ROA is positively correlated indicating that when the total asset of firms increases, its profits also increase. This result is consistent with the results of Antwi-Asare \& Addison (2000) who studied the financial sector reforms have influenced bank performance in Ghana. This result also refutes the results of Mensah-Mawutor \& Awah (2015); Tetteh (2014) that the ROA is negatively correlated with bank SIZE among Ghanaian banks. Bank overheads also have a negative correlation with ROA as expected. However this result is not in agreement with the results of Naceur (2003) whose results indicated a positive correlation between overheads and ROA among banks. The results also shows that bank LOANS and bank DEPOSITS correlates negatively with ROA and is consistent with the findings of Anbar \& Alper (2011). Consistent with the findings of Naceur (2003), our findings was indicated bank CAPITAL correlates positively with ROA among Ghanaian banks. The results of our macro-level variables 
indicated that ROA has a negative relationship with GDP growth and exchange rate while is positively correlated with interest rate.

\subsection{Empirical Results from Panel Data Analysis}

Table 4 below shows two different but related models of the empirical results of this study to establish the factors that determines profitability in the Ghanaian banking industry in relation to our sample. The Fixed Effect model was first run and we assume that unobserved effects are correlated with the factors of profitability. We then run the Random Effects model where the initial assumptions of correlation are reversed on the same covariates. The Hausman specification test was therefore used to determine and select one model that best suits the scenario for our sample. Table 4 below also shows the parameters of estimation and standard errors obtained from the fixed effects model and the random effects model and the between effects model with ROA as the dependent variable.

We first begin the regression analysis with the FE model which we observed that SIZE (natural log. of total assets) and deposits to total assets are not significant and impacting on profitability among our firm-level variables. Loans to total assets are highly significant and impacts on profitability positively. This positive relationship indicates that the banks are able to generate more profits when they give out more loans to customers through the interest they charge. Capital to total assets is also significant and impacts positively on ROA and this indicate that as banks are able to hold more capital in their reserve, it increases their capital adequacy ratio which makes them liquid and profitable. Lastly on the firm-level variables, overhead to total assets is highly significant and impacts negatively on the profitability variable. This indicates that as the operational cost of the banks increases, their profit also decreases. All our macro-level variables were insignificant except exchange rate which has a negative impact on ROA.

For the RE model the research observes same results as the FE model in terms of our loan, deposits, capital and overhead variables. The only difference was the bank size which under the RE model was highly significant and impacts positively on ROA. This means that according to the RE model bank size measured as natural log. of total assets is very important and highly determines profit in the Ghanaian banking industry. The results however showed no significance and impact of our macro-level variables on ROA under the RE model. 


\section{Macrothink}

Asian Journal of Finance \& Accounting ISSN 1946-052X 2016, Vol. 8, No. 2

Table 4. Regression Models

\section{VARIABLES}

FEMODEL (ROA)

REMODEL(ROA)

\begin{tabular}{lcc}
\hline SIZE & 0.194 & $0.791^{* * *}$ \\
& $(0.234)$ & $(0.182)$ \\
\hline LOAN & $0.0612^{* *}$ & $0.0440^{*}$ \\
& $(0.0227)$ & $(0.0183)$ \\
\hline DEP. & -0.0121 & 0.00404 \\
& $(0.0231)$ & $(0.0116)$ \\
\hline CAP. & $0.0964^{*}$ & $0.0625^{*}$ \\
& $(0.0383)$ & $(0.0249)$ \\
\hline OVER. & $-0.316^{* * *}$ & $-0.424^{* * *}$ \\
& $(0.0683)$ & $(0.0588)$ \\
\hline GDP & -0.0619 & -0.0300 \\
& $(0.0677)$ & $(0.0768)$ \\
\hline EXR & $-1.635^{*}$ & -0.340 \\
& $(0.709)$ & $(0.686)$ \\
\hline ITR & 0.0515 & 0.0412 \\
& $(0.0957)$ & $(0.111)$ \\
\hline cons & -0.792 & $-13.73^{*}$ \\
& $(6.487)$ & $(5.476)$ \\
\hline
\end{tabular}

R-sq

0.397

AIC

576.0 -

BIC

$602.3-$

$\mathrm{F}$

$8.878-$

$\mathrm{N}$

$137 \quad 137$

Standard errors in parentheses

$* \mathrm{p}<0.05, * * \mathrm{p}<0.01, * * * \mathrm{p}<0.00$

Source: authors' estimations

The Hausman specification test was performed on the Fixed and Random effect model which calculated a chi2 of $31.15(\mathrm{p}>\mathrm{chi} 2=0.0001)$.

$$
\begin{aligned}
& \operatorname{chi} 2(8)=(b-B)^{\prime}\left[\left(V_{-} b-V_{-} B\right)^{\wedge}(-1)\right](b-B) \\
& =\quad 31.15 \\
& \text { Prob }>\text { chi } 2=\quad 0.0001 \\
& \text { (V_b-V_B is not positive definite) }
\end{aligned}
$$


With this result we confidently accept the result of the fixed effect model as the appropriate result for this study.

\section{Conclusion and Recommendation}

This study investigates the factors of bank-specific characteristics and macroeconomic indicators on bank's profitability in the Ghanaian Banking industry for the 2007-2014 periods. The bank specific variables used in this study include the size of the bank loans, deposit and overheads whilst the macroeconomic variables used were GDP growth, interest rate and exchange rate. The results from the fixed effect regression models indicated that bank loans and capital impacts positively on the profitability of Ghanaian banks. Also the banks should reduce their overhead cost to gain more profit since the results showed a highly negative significance on profitability. Bank size and bank deposit did not have any impact on profitability. The results further showed that with the macroeconomic indicators, only exchange rate was found to be impacting negatively on profitability.

\section{References}

Anarfi, D., \& Boateng, K. A. (2016). The Relationship between Working Capital Management and Profitability: Evidence from the Czech Agric and Forest Industry. Researchers World, 7(3), 109.

Antwi-Asare, T. O., \& Addison, E. K. Y. (2000). Financial sector reforms and bank performance in Ghana. Overseas Development Institute.

Arias, J. C. (2011). Banking profitability determinants. Volume 4-Number 2-July 2011-Semiannual Publication, 4(2), 209.

Ayadi, R., Arbak, E., Naceur, S. B., \& De Groen, W. P. (2015).Financial Development, Bank

Efficiency, and Economic Growth Across the Mediterranean. In Economic and Social Development of the Southern and Eastern Mediterranean Countries (pp. 219-233). Springer International Publishing.

Babalola, Y. A. (2012). The determinants of bank's profitability in Nigeria. Journal of Money, Investment and Banking, 24, 6-16.

Berger, A. (1995). The Relationship Between Capital and Earnings in Banking. Journal of Money, Credit and Banking, 27, 404-431. https://doi.org/10.2307/2077876

Berger, A.N. and Hanweck, G.A. and Humphrey, D.B. (1987). "Competitive Viability in Banking: Scale, Scope and Product Mix Economies". Journal of Monetary Economics, 20, 501-520. https://doi.org/10.1016/0304-3932(87)90039-0

Flamini, V., Schumacher, M. L., \& McDonald, M. C. A. (2009). The determinants of commercial bank profitability in Sub-Saharan Africa (No. 9-15). International Monetary Fund. https://doi.org/10.5089/9781451871623.001

Goodhart, C. (Ed.). (2016). Financial development and economic growth: Explaining the links. Springer. 
Haghighat, J., and Nasrin. (2004). Bank Efficiency by data envelopment analysis (case study Agricultural Bank). Economic Journal, 9, 171 -135.

Jahan, N. (2012). Determinants of bank's profitability: Evidence from Bangladesh. Indian Journal of Finance, 6(2), 32-38.

Jamal, A. A. A., Hamidi, M., \& Karim, M. R. A. (2012). Determinants of Commercial Banks' Return on Asset: Panel Evidence from Malaysia. International Journal of Commerce, Business and Management, 1(3), 55-62.

Lartey, V. C., Antwi, S., \& Boadi, E. K. (2013). The relationship between liquidity and profitability of listed banks in Ghana. International Journal of Business and Social Science, $4(3)$.

Lee, J. D., \& Heshmati, A. (Eds.). (2009). Productivity, efficiency, and economic growth in the Asia-Pacific region. Physica-Verlag Heidelberg. https://doi.org/10.1007/978-3-7908-2072-0

Mensah-Mawutor, J. K., \& Fred, A. (2015). Assessment of Efficiency and Profitability of Listed Banks in Ghana. Accounting and Finance Research, 4(1), p164.

Mishkin, F. S. (2007). The economics of money, banking, and financial markets. Pearson education.

Naceur S. B. (2003). Determinants of the Tunisian Banking Industry Profitability: Panel Evidence. Frontiers in Finance and Economics, 5(1), 106-130. https://doi.org/10.1016/j.ribaf.2006.05.002

Naceur, S. B., \& Ghazouani, S. (2007). Stock markets, banks, and economic growth: Empirical evidence from the MENA region. Research in International Business and Finance, 21(2), 297-315.

Nwaeze, C., Michael, O., \& Nwabekee, C. E. (2014). Financial Intermediation and Economic Growth in Nigeria (1992-2011). The Macrotheme Review, 3(6), 124-142.

Obamuyi, T. M. (2013). Determinants Of Banks'Profitability In a Developing Economy: Evidence From Nigeria. Organizations and markets in emerging economies, 2, 97-111.

Oladele, P. O., Sulaimon, A. A., \& Akeke, N. I. (2012). Determinants of bank performance in Nigeria. International Journal of Business and Management Tomorrow, 2(2), 1-4.

Shahbaz, M., \& Lean, H. H. (2012). Does financial development increase energy consumption? The role of industrialization and urbanization in Tunisia. Energy policy, 40, 473-479. https://doi.org/10.1016/j.enpol.2011.10.050

Tetteh, M. L. (2014). Local versus foreign bank performance: the case of Ghana. Banks and Bank Systems, 9(3), 43-49. 


\section{Macrothink}

Asian Journal of Finance \& Accounting ISSN 1946-052X

Van Nieuwerburgh, S., Buelens, F., \& Cuyvers, L. (2006). Stock market development and economic growth in Belgium. Explorations in Economic History, 43(1), 13-38. https://doi.org/10.1016/j.eeh.2005.06.002

Yaron, J., Benjamin, M., \& Charitonenko, S. (1998). Promoting efficient rural financial intermediation. The World Bank Research Observer, 13(2), 147-170. https://doi.org/10.1093/wbro/13.2.147 